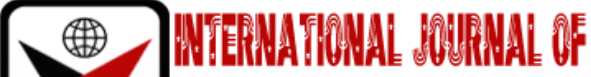 \\ בाmरक
}

ISSN 2278-0211 (Online)

\section{Recurrence and Tooth Mobility Associated with Gingival Enlargements in Patients Attending a Tertiary Hospital in Lagos, Nigeria}

Olagundoye Olufemi
Lecturer, Department of Preventive Dentistry,
Lagos state University College of Medicine Ikeja Lagos, Nigeria
Sorunke Modupeore
Senior Lecturer, Department of Preventive Dentistry,
Lagos state University College of Medicine Ikeja Lagos, Nigeria
Onigbinde Olubunmi
Senior Lecturer, Department of Preventive Dentistry,
Lagos state University College of Medicine Ikeja Lagos, Nigeria
Ladeji Adeola
Senior Lecturer, Department of Oral pathology and Oral Medicine,
Lagos state University College of Medicine Ikeja Lagos, Nigeria
Kuye Olasunkanmi
Lecturer, Department of Oral and Maxillofacial Surgery,
Lagos state University College of Medicine Ikeja Lagos, Nigeria

\begin{abstract}
:
Background: Gingival enlargements has attracted much review in literature, however sequelae such as recurrence and tooth mobility and associated factors demands more research attention.

Objective-This study assessed the prevalence and distribution of recurrence and tooth mobility associated with gingival enlargements and their predisposing factors in Lagos, Nigeria.

Methods-This is a retrospective study of 138 patients seen over 5 years at the Dental Centre of the Lagos state University Teaching Hospital Ikeja, Lagos, Nigeria. Records were accessed from the Oral Pathology and medical records department of the same institution. SPSS 21 was used for data analysis; descriptive statistics was carried out for both continuous and categorical variables. Chi square and fisher's exact were carried out as appropriate and logistic regression was used to test the covariates. Significance was determined at $p \leq 0.05$.

Results- Prevalence of recurrence and tooth mobility was $26.8 \%$ and $39.1 \%$ respectively. Tooth mobility was highest among the 31-40-year-oldswhile recurrence was commonest in the 21-40-year-olds. Maxillary anterior sextant and the buccal/labial location were commonest sites for recurrence and tooth mobility. Pyogenic granuloma has the highest prevalence of tooth mobility (50\%) and recurrence (67.6\%). There is significant relationship between the dependent variables and tooth malpositioning and oral hygiene $(p<0.05)$.Logistic regression reveals significant relationship between tooth mobility and recurrence, poor oral hygiene, tooth malpositioning, age and medications $(p<0.05)$. Recurrence has statistical significance with educational level, poor oral hygiene, tooth mobility and malpositioning $(p<0.05)$.

Conclusion- Poor oral hygiene and tooth malpositioning werefactors significantly associated with both recurrence and tooth mobility recorded with gingival enlargements in this study. Thisemphasizes the need for improvement in oral hygiene and early institution of orthodontic interception to correct malposed teeth in preventing these sequelae in patients that develops gingival enlargement.
\end{abstract}

Keywords: Gingival, recurrence, malpositioning, mobility, enlargement

\section{Introduction}

Gingival enlargements (GE)are overgrowths usually slow growing lesions commonly found on the marginal or attached gingiva or both arising from interdental papilla or the facial tissues [1]. A large proportion of these lesions are initiated by exposure to chronic irritation and low-grade trauma from sub gingival plaque and calculus, tobacco smoking, irregular or sharp margins of carious or fractured tooth/fillings and friction from ill-fitting dentures and faulty restorations [1-5]. In females, this irritation is further aggravated by the effect of oestrogen and progesterone [1-5]. GEare 
classified into five groups; inflammatory enlargement, drug-induced enlargement, enlargement associated with systemic diseases or conditions, neoplastic enlargement, and false enlargement [2]. Kfir et al termed some inflammatory enlargements (pyogenic granuloma (PG), peripheral giant cell granuloma (PGCG), fibrous hyperplasia (FH) and peripheral ossifying fibroma (POF)) as Reactive gingival lesions [3].In a study by Effiom et al, Pyogenic granuloma was the most common lesions constituting 57\%, of which pregnancy induced accounted for 9.5\%, fibroepithelial hyperplasia and peripheral ossifying fibroma were $14.3 \%$ and $10.7 \%$ respectively [4]. The female-to-male ratio ranged from $1.7: 1$ to $2.5: 1$ from different studies [4-6]. The lesions are most prevalent in the second to the third decade of life and least common in the 7th decade and above [4-6]. Buccal gingiva is the commonest site of occurrence while distribution on maxilla and mandible is similar [4-6].

Complications associated with gingival enlargementmay include retained primary teeth, delayed eruption of permanent teeth, increased distal spacing, poor plaque control, poor mastication, affected speech, esthetics, and malocclusion [7]. Recurrence is characteristic of Juvenile ossifying fibroma and Pyogenic granuloma. In a study, recurrent lesions accounted for 2.9\%,majority of which were pyogenic granuloma [4]. In Benin, Nigeria, Azodo and coworkers reported only 2 cases of recurrent lesion both of which were Peripheral ossifying fibroma [8].There is dearth of data on tooth mobility as a sequela of gingival enlargements, hence, the decision to carry out this study. In addition, associated factors for both recurrence and tooth mobility demand more research attention.

\section{Objective}

This study determined the prevalence and distribution of recurrence and tooth mobility associated with gingival enlargements in patients attending the Periodontology clinic of the dental Centre, Lagos University Teaching Hospital (LASUTH) Ikeja Lagos. It also assessed associated factors of recurrence and tooth mobility inthese patients.

\section{Methods}

This is a retrospective cross-sectionalstudy of 138 patients seen over 5 years at the Dental Centre of LASUTH, Ikeja, Lagos, Nigeria. Convenient sampling method was used,records were accessed from the Oral Pathology and medical records departments of the same institution The mouth was divided into sextants viz; upper anterior sextant (UAS), upper left posterior sextant (ULPS), upper right posterior sextant (URPS),lower anterior sextant (LAS), lower left posterior sextant (LLPS), lower right posterior sextant (LRPS). Lesions included in the study were Pyogenic granuloma (PG), Peripheral ossifying fibroma (POF), Peripheral fibroma (PF), Peripheral giant cell granuloma (PGCG), fibrous hyperplasia (FH), Congenital gingival granular cell tumor (CGGCT),Poorly differentiated ossifying fibroma (PDSCC), Squamous papilloma (SP) and Peripheral ameloblastoma (PA).

SPSS 21 was used for data analysis while descriptive statistics was carried out for both continuous and categorical variables. Chi square and fisher's exact were carried out as appropriate for hypothesis testing and binarylogistic regression was used to test the covariates and control for confounders. Significance was determined at $\mathrm{p} \leq 0.05$.

\section{Results}

Mean age of the participants was36.6 \pm 17.7 years while male to female ratio was $1: 2.2$. Skewness was0.215 signifying a normally distributed sample. Prevalence of recurrence and tooth mobility was 26.8\% (37)and 39.1\% (54) respectively. Tooth mobility was highest among the 31-40-year-oldwhile recurrence was commonest in the 21-40-yearold (fig 1). The maxilla, anterior sextant (fig 2)and the buccal/labial location were commonest sitesof recurrence and tooth mobility(Table 1). Pyogenic granuloma has the highest prevalence of tooth mobility50\% (27) and recurrence 67.6\% (25) while the least was Squamous papilloma (0\%) and Congenital granular cell tumor (0\%) for both (Figure 3).

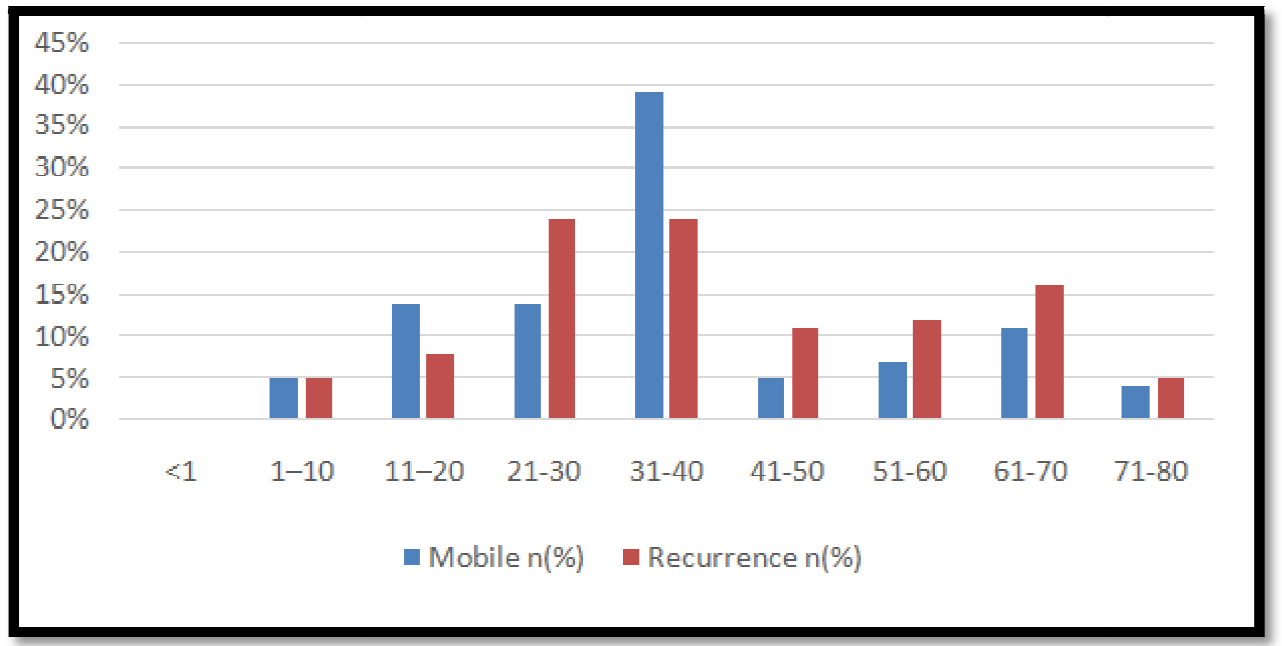

Figure 1: Prevalence of Tooth Mobility and Recurrence by Age Groups 


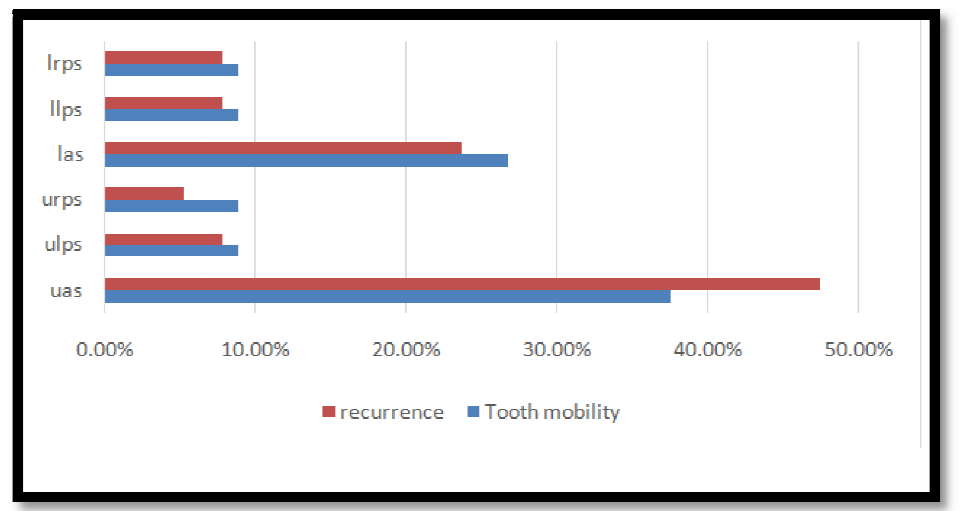

Figure 2: Prevalence of Tooth Mobility and Recurrence by Sextants

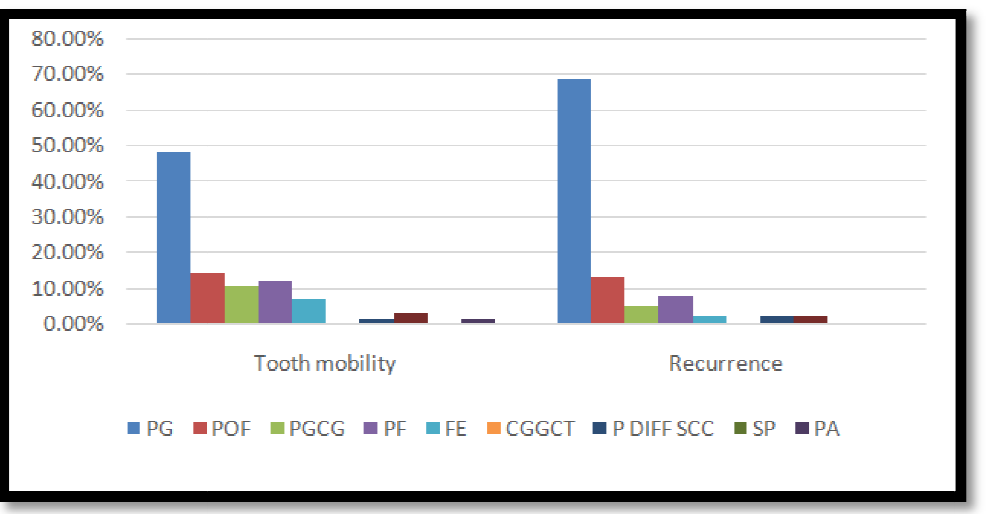

Figure 3: Prevalence of the Lesions by Tooth Mobility and Recurrence

\begin{tabular}{|c|c|c|c|}
\hline \multicolumn{2}{|c|}{ Variable } & \multirow{2}{*}{$\begin{array}{c}\begin{array}{c}\text { Mobile n(\%) } \\
\text { Total 54 }\end{array} \\
5(9.3 \%) \\
\end{array}$} & \multirow{2}{*}{$\begin{array}{c}\begin{array}{c}\text { Recurrence n(\%) } \\
\text { Total } 37\end{array} \\
3(8.1 \%) \\
\end{array}$} \\
\hline Educational level & Uneducated (formal) & & \\
\hline & Primary & $13(24.1 \%)$ & $12(32.4 \%)$ \\
\hline & Secondary & $9(16.7 \%)$ & $6(16.2 \%)$ \\
\hline & Tertiary & $28(51.9 \%)$ & $16(43.2 \%)$ \\
\hline \multirow[t]{2}{*}{ Sex } & Male & $19(35.2 \%)$ & $14(37.8 \%)$ \\
\hline & female & $35(64.8 \%)$ & $23(62.2 \%)$ \\
\hline \multirow[t]{2}{*}{ Jaw } & Maxilla & $27(50 \%)$ & $22(59.5 \%)$ \\
\hline & Mandible & $27(50 \%)$ & $15(40.5 \%)$ \\
\hline \multirow[t]{3}{*}{ Location } & Buccal/labial & $39(72.2 \%)$ & $25(67.6 \%)$ \\
\hline & Lingual/palatal & $4(7.4 \%)$ & $5(13.5 \%)$ \\
\hline & Buccolabial/palatal & $11(20.4 \%)$ & $7(18.9 \%)$ \\
\hline \multirow[t]{2}{*}{ Attachment } & Pedunculated & $30(55.6 \%)$ & $20(54.1 \%)$ \\
\hline & Sessile & $24(44.4 \%)$ & $17(45.9 \%)$ \\
\hline \multirow[t]{2}{*}{ Malocclusion } & Yes & $49(90.7 \%)$ & $27(73 \%)$ \\
\hline & No & $5(9.3 \%)$ & $10(27 \%)$ \\
\hline \multirow[t]{3}{*}{ Oral hygiene } & Good & $5(9.3 \%)$ & $4(10.8 \%)$ \\
\hline & Fair & $9(16.7 \%)$ & $6(16.2 \%)$ \\
\hline & Poor & $40(74.1 \%)$ & $27(73 \%)$ \\
\hline \multirow[t]{4}{*}{ Underlying conditions } & None & $48(88.9 \%)$ & $35(94.6 \%)$ \\
\hline & HIV & $3(5.6 \%)$ & $0(0 \%)$ \\
\hline & Medications & $1(1.9 \%)$ & $1(2.7 \%)$ \\
\hline & Pregnancy & $2(3.7 \%)$ & $1(2.7 \%)$ \\
\hline
\end{tabular}

Table 1: Description of the Variables by Tooth Mobility and Recurrence

There is significant difference in the age groups $(\mathrm{p}<0.05)$, lesions, underlying conditions,malocclusion and oral hygienep $=0.01$ for tooth mobility while this applies to malocclusion and oral hygiene for recurrence of the lesions $(p=0.01)$ on bivariate analysis (Table $2 \& 2 \mathrm{~b}$ ).

Logistic regression reveals significant relationship between age group 31-40 ( $p=0.01), P G, P O F \quad P F(p \leq 0.05)$ lingual/palatal location $(p=0.05)$, recurrence $(p=0.01)$, poor oral hygiene $(p=0.01)$, tooth malpositioning $(p=0.01)$ and medications $\mathrm{p}<0.05$.(Table $4 \& 3 \mathrm{~b}$ ).Recurrence has statistical significancerelationship with secondary level of educational 
$(\mathrm{p}<0.05)$, poor oral hygiene $(\mathrm{p}=0.01)$, and tooth mobility $\mathrm{p}<0.05$. Omnibus test of coefficients and HosmerLemeshow tests attests to the goodness of the fit of the model (Table 4).

\begin{tabular}{|c|c|c|c|c|c|c|c|}
\hline \multicolumn{2}{|c|}{ Variable } & \multirow{2}{*}{$\begin{array}{c}\begin{array}{c}\text { Non mobile } \\
\text { (84) }\end{array} \\
2\end{array}$} & \multirow{2}{*}{$\begin{array}{c}\text { Mobile } 54 \\
0\end{array}$} & \multirow{2}{*}{$\begin{array}{c}\begin{array}{c}\mathbf{P} \\
\text { Value }\end{array} \\
0.02^{*}\end{array}$} & \multirow{2}{*}{$\begin{array}{c}\text { No } \\
\text { Recurrence } \\
(\mathbf{1 0 1})\end{array}$} & \multirow{2}{*}{$\begin{array}{c}\text { Recurrence } \\
\mathbf{3 7} \\
0\end{array}$} & \multirow{2}{*}{$\begin{array}{c}\text { P Value } \\
0.62\end{array}$} \\
\hline $\begin{array}{l}\text { Age groups } \\
\text { (years) }\end{array}$ & $<1$ & & & & & & \\
\hline & $1-10$ & 1 & 3 & & 2 & 2 & \\
\hline & $11-20$ & 11 & 6 & & 15 & 2 & \\
\hline & $21-30$ & 21 & 8 & & 20 & 9 & \\
\hline & $31-40$ & 16 & 22 & & 29 & 9 & \\
\hline & $41-50$ & 10 & 3 & & 9 & 4 & \\
\hline & $51-60$ & 9 & 4 & & 8 & 5 & \\
\hline & $61-70$ & 14 & 6 & & 14 & 6 & \\
\hline & $71-80$ & 0 & 2 & & 2 & 0 & \\
\hline \multirow[t]{2}{*}{ Sex } & Male & 24 & 19 & 0.26 & 29 & 14 & 0.21 \\
\hline & female & 60 & 35 & & 72 & 23 & \\
\hline \multirow[t]{4}{*}{$\begin{array}{c}\text { Educational } \\
\text { level }\end{array}$} & $\begin{array}{l}\text { Uneducated } \\
\text { (formal) }\end{array}$ & 9 & 5 & 0.34 & 11 & 3 & 0.12 \\
\hline & Primary & 13 & 13 & & 14 & 12 & \\
\hline & Secondary & 17 & 9 & & 20 & 6 & \\
\hline & Tertiary & 45 & 27 & & 56 & 16 & \\
\hline \multirow[t]{9}{*}{ Lesions } & PG & 61 & 27 & $0.01^{*}$ & 63 & 25 & 0.84 \\
\hline & POF & 16 & 8 & & 19 & 5 & \\
\hline & PGCG & 0 & 6 & & 4 & 2 & \\
\hline & $\mathrm{PF}$ & 2 & 7 & & 6 & 3 & \\
\hline & $\mathrm{FE}$ & 1 & 4 & & 4 & 1 & \\
\hline & CGGCT & 2 & 0 & & 2 & 0 & \\
\hline & PDSCC & 1 & 1 & & 1 & 1 & \\
\hline & SP & 1 & 0 & & 1 & 0 & \\
\hline & PA & 0 & 1 & & 1 & 0 & \\
\hline
\end{tabular}

Table 2: Bivariate Relationship between Tooth Mobility, Recurrence and the Independent Variables

\begin{tabular}{|c|c|c|c|c|c|c|c|}
\hline \multicolumn{2}{|c|}{ Variable } & \multirow{2}{*}{$\begin{array}{c}\begin{array}{c}\text { Non mobile } \\
\text { (84) }\end{array} \\
45\end{array}$} & \multirow{2}{*}{$\begin{array}{c}\text { Mobile (54) } \\
27\end{array}$} & \multirow{2}{*}{$\begin{array}{c}\mathbf{P} \\
\text { Value } \\
0.84 \\
\end{array}$} & \multirow{2}{*}{$\begin{array}{c}\begin{array}{c}\text { No } \\
\text { Recurrence } \\
(\mathbf{1 0 1})\end{array} \\
50\end{array}$} & \multirow{2}{*}{$\begin{array}{c}\begin{array}{c}\text { Recurrence } \\
\text { (37) }\end{array} \\
22\end{array}$} & \multirow{2}{*}{$\begin{array}{c}\begin{array}{c}\mathbf{P} \\
\text { Value }\end{array} \\
0.20 \\
\end{array}$} \\
\hline Jaw & Maxilla & & & & & & \\
\hline & Mandible & 39 & 27 & & 51 & 15 & \\
\hline \multirow[t]{6}{*}{ Sextant } & UAS & 35 & 20 & 0.84 & 38 & 17 & 0.97 \\
\hline & ULPS & 8 & 5 & & 10 & 3 & \\
\hline & URPS & 3 & 4 & & 5 & 2 & \\
\hline & LAS & 24 & 15 & & 30 & 9 & \\
\hline & LLPS & 8 & 5 & & 10 & 3 & \\
\hline & LRPS & 6 & 5 & & 8 & 3 & \\
\hline \multirow[t]{3}{*}{ Location } & Buccal/labial & 53 & 39 & 0.12 & 67 & 25 & 0.52 \\
\hline & Lingual/palatal & 18 & 4 & & 17 & 5 & \\
\hline & $\begin{array}{c}\text { Buccolabial } \\
\text { /palatal }\end{array}$ & 13 & 11 & & 17 & 7 & \\
\hline \multirow[t]{2}{*}{ Attachment } & Pedunculated & 50 & 30 & 0.40 & 60 & 20 & 0.35 \\
\hline & Sessile & 34 & 24 & & 41 & 17 & \\
\hline \multirow[t]{2}{*}{ Malocclusion } & Yes & 16 & 49 & $0.01^{*}$ & 38 & 27 & $0.01^{*}$ \\
\hline & No & 68 & 5 & & 63 & 10 & \\
\hline \multirow[t]{4}{*}{ Oral hygiene } & Good & 30 & 5 & $0.01^{*}$ & 31 & 4 & $0.01^{*}$ \\
\hline & Fair & 39 & 9 & & 42 & 6 & \\
\hline & Poor & 15 & 40 & & 28 & 27 & \\
\hline & None & 78 & 48 & $0.02^{*}$ & 91 & 35 & 0.13 \\
\hline \multirow[t]{3}{*}{$\begin{array}{l}\text { Underlying } \\
\text { conditions }\end{array}$} & HIV & 0 & 3 & & 3 & 0 & \\
\hline & Medications & 4 & 1 & & 4 & 1 & \\
\hline & Pregnancy & 2 & 2 & & 3 & 1 & \\
\hline
\end{tabular}

Table 3: Bivariate Relationship between Tooth Mobility, Recurrence and the Independent Variables *Significant 


\begin{tabular}{|c|c|c|c|c|c|c|}
\hline Goodness of fit test & Tooth & \multicolumn{5}{|c|}{ Recurrence } \\
\hline $\begin{array}{l}\text { Omnibus test of model } \\
\text { coefficient }\end{array}$ & $0.001^{*}$ & \multicolumn{5}{|c|}{$0.001^{*}$} \\
\hline HosmerLemeshow test & 0.678 & \multicolumn{5}{|c|}{0.835} \\
\hline \multirow[t]{2}{*}{ Variable } & \multicolumn{3}{|c|}{ Mobility } & \multicolumn{3}{|c|}{ Recurrence } \\
\hline & Significance & $\mathrm{df}$ & Odd & Significance & $\mathrm{df}$ & Odd \\
\hline \multicolumn{7}{|l|}{ Age groups } \\
\hline$<1$ & 0.25 & 1 & 1.353 & 0.39 & 1 & 0.756 \\
\hline $01-0 c t$ & 0.15 & 1 & 2.102 & 0.3 & 1 & 1.088 \\
\hline Nov-20 & 0.84 & 1 & 0.041 & 0.23 & 1 & 1.433 \\
\hline $21-30$ & 0.13 & 1 & 2.349 & 0.6 & 1 & 0.28 \\
\hline $31-40$ & $0.01^{*}$ & 1 & 6.959 & 0.57 & 1 & 0.315 \\
\hline $41-50$ & 0.19 & 1 & 1.71 & 0.76 & 1 & 0.095 \\
\hline $51-60$ & 0.48 & 1 & 0.509 & 0.34 & 1 & 0.928 \\
\hline $61-70$ & 0.32 & 1 & 0.972 & 0.76 & 1 & 0.096 \\
\hline \multicolumn{7}{|l|}{ Sex } \\
\hline Male & 0.37 & 1 & 0.795 & 0.21 & 1 & 1.566 \\
\hline \multicolumn{7}{|l|}{ Educational level } \\
\hline Primary & 0.73 & 1 & 0.119 & 0.61 & 1 & 0.257 \\
\hline Secondary & 0.25 & 1 & 1.33 & $0.02^{*}$ & 1 & 5.836 \\
\hline Tertiary & 0.73 & 1 & 0.122 & 0.52 & 1 & 0.41 \\
\hline \multicolumn{7}{|l|}{ Lesions } \\
\hline PG & $0.01^{*}$ & 1 & 27.897 & 0.67 & 1 & 0.192 \\
\hline POF & $0.01 *$ & 1 & 8.572 & 0.45 & 1 & 0.583 \\
\hline PGCG & 0.46 & 1 & 0.536 & 0.73 & 1 & 0.121 \\
\hline PF & $0.02^{*}$ & 1 & 9.403 & 0.67 & 1 & 0.186 \\
\hline $\mathrm{FE}$ & 0.17 & 1 & 5.72 & 0.72 & 1 & 0.134 \\
\hline CGGCT & 0.06 & 1 & 3.457 & 0.39 & 1 & 0.756 \\
\hline PDSCC & 0.25 & 1 & 1.353 & 0.46 & 1 & 0.536 \\
\hline PA & 0.77 & 1 & 0.085 & 0.46 & 1 & 0.536 \\
\hline SP & 0.08 & 1 & 3.043 & 0.54 & 1 & 0.375 \\
\hline
\end{tabular}

Table 4: Multivariate Analysis to Determine Associated Factors of Tooth Mobility and Recurrence Binary Logistic Regression

*Significant

\begin{tabular}{|c|c|c|c|c|c|c|c|}
\hline \multirow{3}{*}{$\begin{array}{c}\begin{array}{c}\text { Variable } \\
\text { Categories }\end{array} \\
\text { Jaw }\end{array}$} & \multicolumn{3}{|c|}{ Mobility } & \multicolumn{4}{|c|}{ Recurrence } \\
\hline & \multirow[t]{2}{*}{ Significance } & \multirow[t]{2}{*}{$\mathrm{df}$} & Odd & \multirow[t]{2}{*}{ Significance } & \multirow[t]{2}{*}{$\mathrm{df}$} & \multicolumn{2}{|c|}{ Odd } \\
\hline & & & & & & & \\
\hline Maxilla & 0.84 & 1 & 0.043 & 0.27 & 1 & 1.231 & \\
\hline Sextant & & 1 & & & & & \\
\hline UAS & 0.62 & 1 & 0.243 & 0.28 & 1 & 1.180 & \\
\hline ULPS & 0.91 & 1 & 0.014 & 0.73 & 1 & 0.120 & \\
\hline URPS & 0.18 & 1 & 1.790 & 0.89 & 1 & 0.020 & \\
\hline LAS & 0.82 & 1 & 0.053 & 0.50 & 1 & 0.452 & \\
\hline LLPS & 0.91 & 1 & 0.014 & 0.73 & 1 & 0.120 & \\
\hline \multicolumn{8}{|l|}{ Location } \\
\hline Buccal/labial & 0.42 & & 0.639 & 0.99 & 1 & 0.00 & \\
\hline Lingual/palatal & $0.05^{*}$ & 1 & 3.824 & 0.52 & 1 & 0.406 & \\
\hline \multicolumn{8}{|l|}{ Nature } \\
\hline Pedunculated & 0.40 & 1 & 0.703 & 0.70 & 1 & 0.144 & \\
\hline Malocclusion & $0.01^{*}$ & 1 & 69.847 & $0.01^{*}$ & 1 & 13.947 & \\
\hline \multicolumn{8}{|l|}{ Oral hygiene } \\
\hline Fair & $0.01^{*}$ & 1 & 10.994 & $0.04^{*}$ & 1 & 4.305 & \\
\hline Poor & $0.01^{*}$ & 1 & 13.743 & $0.01^{*}$ & 1 & 7.920 & \\
\hline \multicolumn{8}{|l|}{$\begin{array}{l}\text { Underlying } \\
\text { conditions }\end{array}$} \\
\hline HIV & 0.46 & 1 & 0.547 & 0.40 & 1 & 0.728 & \\
\hline Medications & $0.03^{*}$ & 1 & 4.599 & 0.29 & 1 & 1.142 & \\
\hline Pregnancy & 0.35 & 1 & 0.864 & 0.72 & 1 & 0.134 & \\
\hline Recurrence & $0.01^{*}$ & 1 & 2.395 & & & & \\
\hline Mobile & & & & $0.01^{*}$ & 1 & 28.661 & \\
\hline
\end{tabular}

Table 5: Multivariate Analysis to Determine Associated Factors of Tooth Mobility and Recurrence *Significant 


\section{Discussion}

Prevalence of recurrence was $26.8 \%$ and commonest in the middle-aged females (fig 1), this may be because majority of the subjects in this study are females and the hormonal changes common in the gender [4-6]. In agreement with previous studies [9,10], the maxilla, anterior sextants (fig 2) and the buccal/labial location were commonest sites (Table 1).Pyogenic granuloma has the highest prevalence of recurrence (67.6\%) (Figure 3) and commoner with pedunculated lesions[11]. About three-quarters of subjects with recurrent lesions has a form of malocclusion, majority are also related to poor oral hygiene (Table 1). It is known that both factors are interrelated and that reactive gingival lesions are sequel of irritating factors like bacterial plaque and other factors [1-5]. There was significant difference in the malocclusion and oral hygiene for recurrence of the lesions on bivariate analysis (Table 2\&2b). Recurrence has statisticallysignificant relationship with secondary level of education which also supports the higher prevalence in the younger age groups. Malocclusion, poor oral hygiene, and tooth mobility were also significantly associated when confounders were controlled for, all of which may further the irritation of contiguous soft tissues and enhance regrowth.

The fact that none of the lesions were statistically associated with recurrence deviates from previous studies (7,811) which concluded there is high recurrence rate for PG.

Prevalence of tooth mobility was found in almost half of the participants in this study. This may be due to gingival overgrowths predisposing to plaque and calculus stagnation with a sequel of periodontitis and eventual bone loss and mobility[12]. Tooth mobility was highest among female31-40-year-olds[4-6].The maxilla, anterior sextants (fig 2) and the buccal/labial location of lesions were commonest sites for tooth mobility (Table 1)due to the preponderance of these lesions in these sites[9,10]. Pyogenic granuloma has the highest prevalence of tooth mobility (50\%) while there was none found forcongenital granular cell tumor(Figure 3),thereason being associated edentulous ridge in the newborn[13]. Tooth mobility is commoner with pedunculated lesions, this may be because of higher propensity to accumulate plaque and hence, mobility of the lesion. $90.7 \%$ of tooth mobility is found related to tooth malpositioning with majority having poor oral hygiene [14-16].Independent assessment of the covariatesrevealed significant relationship withage group 31-40, the age of highest prevalence of gingival enlargements. PG, POF, PFwere also significantly associated, which arise from their higher prevalence and predisposition to periodontitis $[17,18]$.Recurrence is significantly associated with tooth mobility in a bidirectional fashionhence a further study to determine the cause-and-effect relationship will be necessary.Lingual/palatal location, poor oral hygiene, tooth malpositioning were also significantly associated [14]. Medications which in this case were anti-hypertensives, contraceptives and anticonvulsants (Table 4\& 3b)were also significantly associated factors. Gingival enlargement has been reported to be a common unwanted effect of these medications[19].

\section{Conclusion}

Poor oral hygiene and tooth malpositioning are factors significantly associated with both recurrence and tooth mobility associated with gingival enlargements in this study.Thisemphasizesmaintenance of good oral hygiene and early orthodontic intervention to correct malposed teethare critical in preventing these sequelae of gingival enlargement. Middle aged patients with history of gingival enlargements need specific instructions on the oral health care and prompt management of any tooth misalignment, quarterly oral health-check is strongly recommended.

\section{References}

i. Agrawal, AA. (2015). Gingival enlargements: Differential diagnosis and review of literature. World J Clin Cases, 3(9), 779-788.

ii. Newman, MG., Takei, HH., Klokkevold, PR., \& Carranza, F. A., eds. (2012). Carranza's clinical periodontology (11th ed.). St. Louis, Mo.: Elsevier/Saunders. pp. 84-96. ISBN 978-1-4377-0416-7

iii. Kfir, Y., Buchner, A., \& Hansen, L. S. (1980). Reactive lesions of the gingiva. A clinic- pathological study of 741 cases. J Periodontol, 51:655-61.

iv. Effiom, OA.,Adeyemo, WL., \&Soyele, 00. (2011). Focal reactive lesions of the gingiva: an analysis of 314 cases at a tertiary health institution in Nigeria. Nigerian medical journal: Journal of the Nigeria Medical Association, $52(1), 35$.

v. Akinshipo, WO, Taiwo, AO, Ibikunle, AA, Braimah, RO, Olatunji, SA. (2019). A clinicopathologic analysis of epulides from a subpopulation of Northern Nigeria. Port Harcourt Med J, 13, 93-7.

vi. SorunkeModupeore et al (2021). Prevalence, Pattern and Distribution of Gingival Overgrowths among Patients at the Dental Centre of a Tertiary Hospital in Lagos Nigeria. Saudi J Oral Dent Res, 6(6): 280-285.

vii. da Silva AD, Silva CA, de Camargo M P, Thomaz LA, Furuse C, de Araújo VC.(2011) Recurrent oral pyogenic granuloma in port-wine stain. J CraniofacSurg, Nov;22(6):2356-8. doi: 10.1097/SCS.0b013e318231e33b. PMID: 22134277.

viii. Azodo, CC., Uche, IE.,Ehizele, AO., \&Omoregie, OF. (2017). Esthetically displeasing and recurrent gingival enlargement. A report of two cases. Indian J Oral Health Res, 3:27-31

ix. Gadea RC et al (2017). Oral pyogenic granuloma diagnosis and treatment. RevistaOdontológica Mexicana, 21 (4): 244-252.

X. Sato H, Takeda Y, Satoh M (2002). Expression of the endothelial receptor tyrosine kinase Tie2 in lobular capillary hemangioma of the oral mucosa: An immunohistochemical study. J Oral Pathol Med,;31:432-8.

xi. Bamgbose BO, Kaura MA, Atanda AT, Ajayi OF (2016). Lobular capillary haemangioma of the gingiva: Clinical management and a review of the literature. Niger J Basic ClinSci, 13:107-13 
xii. Athanasia G, Eudoxie P, Sotirios K, Georgios N, Ioannis V (2019). Tooth mobility parameters in chronic periodontitis patients prior to periodontal therapy: A cross-sectional study. Dent Oral Craniofac Res, 5(1): 8-8 doi: 10.15761/DOCR.1000284

xiii. Yıldırım C, Zerener T, Şençimen M, Akgün ÖM, Altuğ HA, Çiçek AF (2017). Congenital Gingival Granular Cell Tumor: A Case Report. J Dent (Shiraz), 18(1):70-72.

xiv. Anne-Marie B(2008). Effects of Malocclusions and Orthodontics on Periodontal Health: Evidence from a Systematic Review. Journal of Dental Education, 72(8).

xv. Sa C, Chengxiaoxue Z, Qing Z (2020). Treatment of Class II malocclusion with tooth movement through the maxillary sinus, American Journal of Orthodontics and Dentofacial Orthopedics,157(1):105-116, ISSN 08895406,

xvi. https://doi.org/10.1016/j.ajodo.2018.08.027.

xvii. Renggli HH, Mühlemann HR (1970). Tooth mobility, marginal periodontitis and malocclusion. Parodontologie. 24(2):39-48. PMID: 5267640

xviii. Sandro A, Lévano L, Alfredo YP (2021). Recurrent oral pyogenic granuloma with alveolar bone loss and tooth mobility: report of an unusual case. Odontoestomatología, 23(37):30 http://dx.doi.org/10.22592/ode2021n37a10.

xix. Paulo H, Luciana SO, Marcelo PN, Victor AM (2016). Coverage Root after after Removing Peripheral Ossifying Fibroma: 5- year Follow-up Case Report. Case Reports in Dentistry, Article ID 6874235, 6 pages, https://doi.org/10.1155/2016/6874235

xx. Janina GD, Denver JL, Daniel ML, George RD.(2020)Severe drug-induced gingival enlargement and periodontitis: A case series with clinical presentation and management, Oral and Maxillofacial Surgery Cases, 6(1):100143,ISSN 2214-5419, https://doi.org/10.1016/j.omsc.2020.100143. 